A Journal of Agricultural Science Publisbed by the California Agricultural Experiment Station

HOST ORGANS ATTACKED BY BACTERIAL CANKER OF STONE FRUITS

EDWARD E. WILSON and WM. B. HEWITT

FACTORS AFFECTING DEVELOPMENT OF THE BACTERIAL CANKER OF STONE FRUITS EDWARD E. WILSON

SOME FACTORS AFFECTING THE SUSCEPTIBILITY OF PLANTS TO FIRE BLIGHT

H. EARL THOMAS and P. A. ARK 


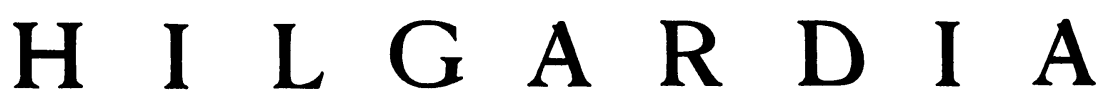

A Journal of Agricultural Science Published by

the California Agricultural Experiment Station

VoL. 12

JANUARY, 1939

No. 4

\section{HOST ORGANS ATTACKED BY BACTERIAL CANKER OF STONE FRUITS ${ }^{1}$}

\author{
EDWARD E. WILSON ${ }^{2}$ AND WM. B. HEWITT ${ }^{3}$
}

\section{INTRODUCTION}

THE MOST DESTRUCTIVE and widespread phase of bacterial canker in Prunus is limb cankers. The organism also attacks leaves, blossoms, fruit, fruit stems, green shoots, and buds. In an earlier article (1), " comparatively little was said concerning the development of these last-named phases of the disease during epidemics. As later observations show, certain infected host organs are important, both from a crop loss standpoint, and from the standpoint of avenues through which the bacteria enter the tree. These infected organs are oversummering sources of the bacteria as well.

British workers are giving considerable attention to a bacteriosis of plums (4) and cherries (5). Since one of the organisms associated with this disease resembles that of the California disease, ${ }^{5}$ the present paper also supplements earlier published $(1,2,3)$ material.

Proof of the Pathogenicity of Cultures from Different Host Organs.Isolations at different times and from material collected in different localities yielded a.number of cultures. Inoculation and reisolation of certain of these cultures proved their pathogenicity to trees of plums, cherries, apricots, and peaches. In order, however to compare representative cultures from the various host organs more directly, extensive inoculations were made into cherry trees of the variety Bing. The results

${ }^{1}$ Received for publication June 14, 1938.

${ }^{2}$ Associate Plant Pathologist in the Experiment Station.

3 Junior Plant Pathologist in the Experiment Station.

"Italic numbers in parentheses refer to "Literature Cited," at the end of this paper.

5 The senior writer has demonstrated $(1,3)$ that Phytomonas prunicola (Wor.) Bergey et al., cause of the disease in England, resembles Phytomonas cerasi (Griffin) Bergey et al., the cause of bacterial canker in California. This evidence will not be reviewed here, nor will the status of $P$. cerasi as a separate species be examined. Suffice it to say that there are reasons for considering as identical $P$. cerasi and $P$. syringae (Van Hall) Bergey et al., the latter causing lilac blight and citrus blast. 
showed that organisms isolated from leaves, blossoms, blossom buds, fruit stems, fruit, and green terminal shoots produced cankers in every respect identical with those produced by Phytomonas cerasi from limb canker of plum (table 1 ).

\section{TABLE 1}

Pathogenicity of Organisms from Various Host Parts to Limbs of Bing Cherry, ApriL, 1936

\begin{tabular}{|c|c|c|c|}
\hline \multirow{2}{*}{ Culture number } & \multicolumn{2}{|c|}{ Source of culture } & \multirow{2}{*}{$\begin{array}{l}\text { Average length of } \\
\text { cankers, in milli- } \\
\text { meters, } 10 \text { days } \\
\text { after inoculation }\end{array}$} \\
\hline & Organ and host & Locality & \\
\hline $1182^{*}$. & Plum limb canker & Placer County & 40 \\
\hline $1996 \ldots$ & Cherry leaf & San Joaquin County & 35 \\
\hline $1998 \ldots$ & Cherry leaf & Sacramento County & 53 \\
\hline $1994 \ldots$ & Cherry blossom & Sacramento County & 59 \\
\hline 1997. & Cherry blossom & San Joaquin County & 47 \\
\hline $1999 \ldots$ & Cherry blossom bud & Sacramento County & 37 \\
\hline 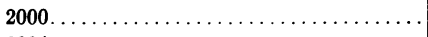 & Apricot blossom bud & Santa Clara County & 35 \\
\hline $2004 \ldots \ldots \ldots \ldots \ldots \ldots \ldots \ldots \ldots \ldots \ldots$ & Plum blossom bud & Placer County & 60 \\
\hline 2005 . & Plum blossom bud & Placer County & 56 \\
\hline 2001 . & Cherry fruit stem & Sutter County & 49 \\
\hline 2002. & Cherry fruit & Sutter County & 63 \\
\hline 2009 . & Plum terminal shoot & Placer County & 70 \\
\hline
\end{tabular}

* Original culture of Phytomonas cerasi derived from a single cell isolation.

\section{RELATIVE IMPORTANCE OF THE DISEASE ON DIFFERENT ORGANS}

Leaf Infection.-Sweet cherries have proved more subject to leaf infection (fig. 1, $A$ ) than other stone fruits. Although an occasional tree suffered severe defoliation, no extensive outbreak occurred. Aside from being a source for further leaf and fruit infection early in the growing season, this leaf phase did not contribute materially to the seriousness of the disease. With cherry bacteriosis, Wormald (5) regards leaf spots as important carryover sources during summer; but in California the dry and (in the interior) warm summers militate against successive waves of leaf and fruit infection that might occur in moister and cooler climates. It is true with this disease, as Wormald (5) maintains for his bacteriosis, that the leaf spots in early stages swarm with bacteria.

Blossom Infection.-Sweet cherries also proved most susceptible to blossom infection (fig. 1, $B$ ), though one rather severe outbreak was observed on apricot and though some varieties of plum are attacked at times. In 1935 blossom infection caused considerable direct loss of the cherry crop in three counties. This phase developed concurrently with serious outbreaks of limb and branch canker. In numerous cases infected 
blossom clusters arising from primary and secondary limbs were foci from which the bacteria passed into such limbs, and thereby instituted the most serious phase of the disease.

The Duarte plum appears comparatively susceptible to attack through blossoms. During 1935 and 1937, when many Duarte trees were killed by the disease, blossom blight was common. It was not always clear whether

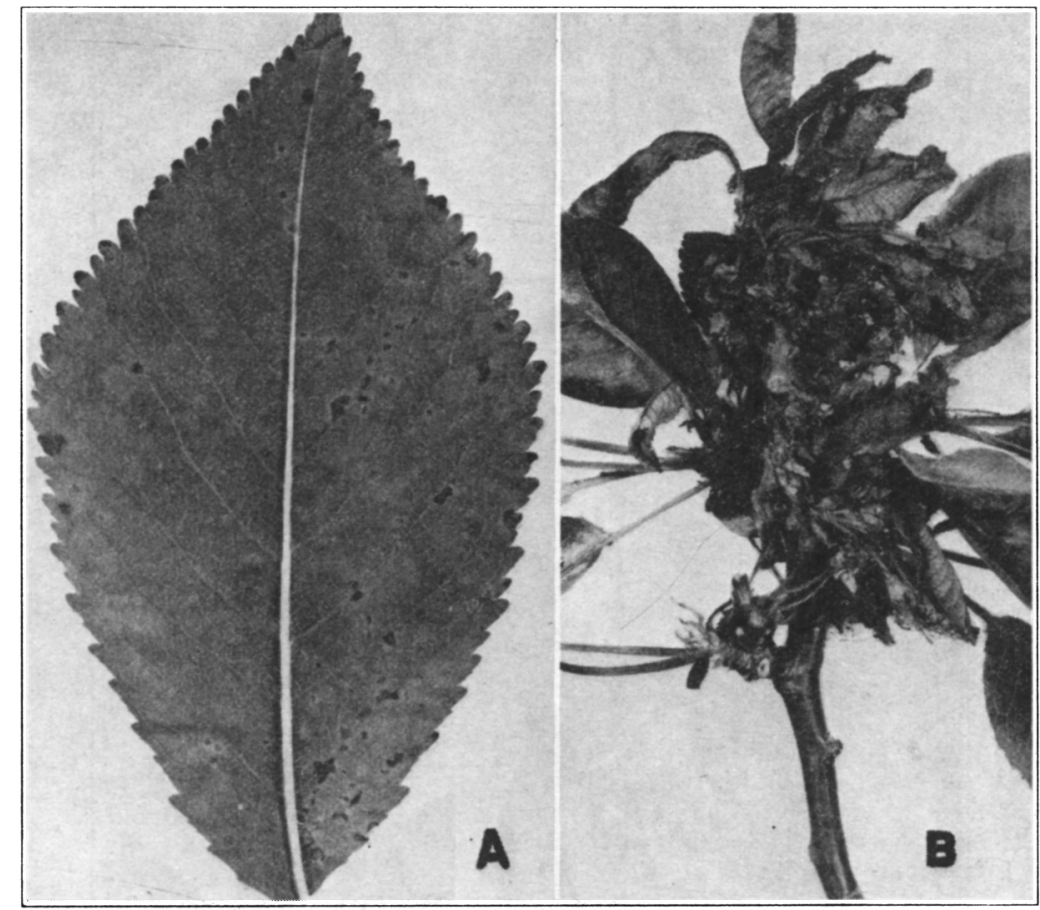

Fig. 1.-Cherry leaf and blossom infection by Phytomonas cerasi. $A$, Typical early stages of leaf-spotting of cherry. $B$, Blossom blight of cherry. The disease has proceeded into the spurs, blighting blossoms and leaves as well.

the bacteria had entered directly through the blossoms at the time the blossoms were emerging, or had entered between the scales of the winter buds. Wormald (5) was also unable to determine this point.

Bud Infection.-The winter buds (fig. 2, B), particularly those enclosing blossoms, were frequently infected. Sweet cherry, apricot, and certain plum varieties exhibited this type of infection more commonly than did peaches or almonds. Death of buds took place concurrently with severe branch and limb lesions of Duarte, Santa Rosa, and Wickson plums during 1935 and 1937. Bud infection contributed to the severity of the disease in three ways : (1) It caused considerable loss of blossom 
buds. (2) It reduced the future fruitfulness of branches. In figure $2, B$ it may be noted all buds were killed for a considerable distance along a fruiting twig. This portion of the twig henceforth fails to produce either leaves or blossom. (3) If the infected buds were on spurs, they were frequently the seats whence the bacteria proceeded to invade the branches

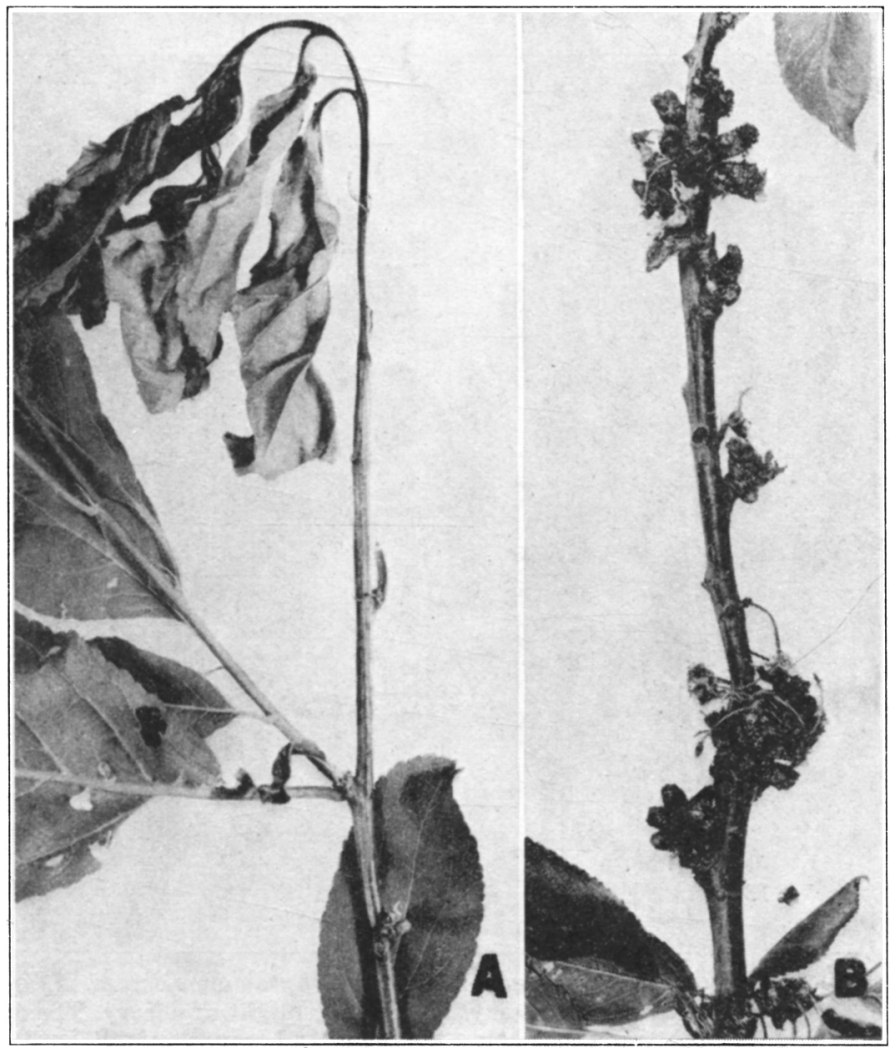

Fig. 2.-Twig and bud infection by Phytomonas cerasi. $A$, Blighted terminal growth of Santa Rosa plum. $B$, Bud, spur, and blossom blight of eherry.

bearing the spurs. This was particularly true in Duarte plum; the death of many branches was traceable to cankers resulting from bud infection. In fact, the susceptibility to bud infection exhibited by the Duarte largely explains the high mortality of Duarte trees during 1935 and 1937. As a later article will show, once infection is established, the bark of Duarte plum is somewhat less favorable to extension of cankers than that of President, a variety suffering little loss in 1935 when it was not attacked through buds. In 1936 buds of President trees were attacked to 
a considerable extent. This appeared to be clearly a case where severity of the disease was conditioned in no small way by the frequency of infection.

Figure 3, C, pictures an infected spur of cherry. Infection probably entered through a blossom bud and, by the time the photograph was made, had extended to the base of the spur. In such cases, especially if

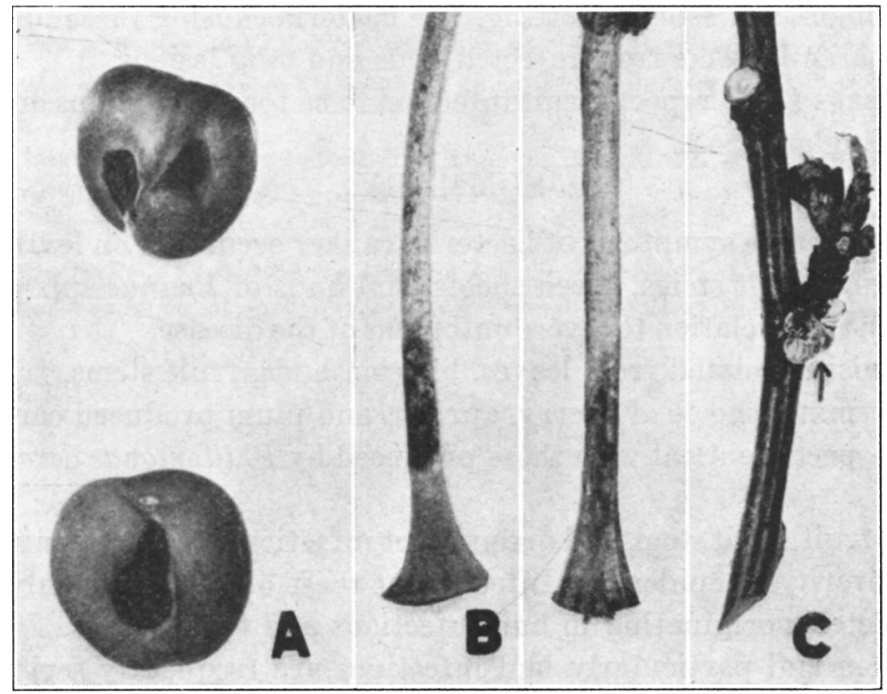

Fig. 3.-Cherry fruit, pedicel, and spur infection by Phytomonas cerasi. $A$, Lesions on fruit of Black Republican cherry. $B$, Lesions on fruit stems of Black Republican cherry. $C$, Blighted spur of Lambert cherry, showing gum (arrow) exuding from its base. Such spurs, particularly those on larger branches, are the foci whence the bacteria may spread through the bark tissue into the branch and thereby establish the more serious canker phase.

the disease extends into the branch, an oversummering source of infection is established. Leaf, fruit, and fruit-stem infection of cherries has been traced to such holdover sources. Infection of cherry buds also occurs with bacteriosis in England (5).

Green-Shoot Infection.-Infection of current terminal growth (fig. $2, A$ ) though often noted in coastal counties, was found only once in the interior districts. In 1937 it developed concurrently with bud and branch infection of Santa Rosa, Wickson, and Duarte plums in the Sierra Nevada foothills. In no case was damage extensive. This green-shoot infection apparently does not play an important part as a carryover source, since the bacteria seemed not to survive the summer in the shoots to any great extent. 
This type of infection is common with the bacteriosis of plums and cherries in England $(4,5)$.

Fruit and Fruit-Stem Infection.-One case of apricot fruit infection and one case of cherry fruit infection (fig. 3, $A$ ) have been reported. Considerable loss of crop was occasioned in the cherry orchard where black, sunken lesions bordered by water-soaked areas developed when the fruits were about half mature. Lesions on fruit stems (fig. $3, B$ ) were also common, as was leaf spotting. The bacteria causing these infections had apparently come from infected buds and twig lesions.

Wormald $(4,5)$ reports fruit infection to be found on plums and cherries in England.

\section{SUMMARY}

The less common symptoms of bacterial canker occurring on leaves, blossoms, fruit, fruit stems, green shoots, and buds of Prunus spp. are discussed in their relation to severe outbreaks of the disease.

Organisms isolated from leaves, blossom buds, fruit stems, fruit and green terminal shoots of cherry, apricot, and plum produced cankers in every respect identical with those produced by Phytomonas cerasi from plum.

Leaf, fruit, fruit stem, and green-shoot infections have not contributed to the severity of epidemics. Infection of these organs commonly arises from bacteria originating in bud infections and twig lesions.

Blossom and particularly bud infections are frequently serious and develop concurrently with outbreaks of limb cankers. Such infections cause direct loss of crop, reduce future fruitfulness of branches, and produce foci from which the bacteria invade large limbs.

The symptoms pictured herein resemble those of a bacteriosis of cherries and plums in England. In other studies the causal bacteria of the two diseases have proved identical. 


\section{LITERATURE CITED}

1. WILSON, EDWARD E.

1931. A comparison of Pseudomonas prunicola with a canker-producing bacterium of stone-fruit trees in California. Phytopath. 21:1153-1161.

2. WILson, Edward E.

1933. Bacterial canker of stone-fruit trees in California. Hilgardia 8:83-123.

3. Wilson, EdWARD E.

1936. Symptomatic and etiologic relations of the canker and the blossom blast of Pyrus and the bacterial canker of Prunus. Hilgardia 10:213-240.

4. Wormald, H.

1930. Bacterial diseases of stone-fruit trees in Britain. II. Bacterial shoot wilt of plum trees. Ann. Appl. Biol. 17:725-744.

5. WORMald, H.

1937. Bacteriosis of stone-fruit trees in Britain. VI. Field observations on bacteriosis of sweet cherry trees. Jour. Pomol. and Hort. Sci. 15:35-48. 
